\title{
Restorasi Onlay Porcelain Fusi Metal Pada Gigi 26 \\ Pasca Perawatan Endodontic
}

\author{
Suryani Catur $\mathbf{S}^{1}$., Dewi Novita $\mathbf{N}^{1}$., Yan Farijz ${ }^{2}$ \\ 1 Program Studi D III Teknik Gigi Poltekkes Tanjunkarang \\ 2 Dokter Gigi Klinik BRI Bandar Lampung
}

\begin{abstract}
Abstrak
Perawatan endodontik dapat menyebabkan berkurangnya kekerasan gigi sebesar 5\% dan kelenturan sebesar $60 \%$. Kita bisa mengatasai masalah ini dengan melakukan restorasi crown atau onlay. Onlay Porcelain Fused To Metal (PFM) ini dapat mempertahankan sebagian besar jaringan gigi yang berhubungan dengan gingival, dan hal ini merupakan suatu pertimbangan periodontal yang sangat membantu. Artikel ini bertujuan memaparkan keberhasilan pembuatan onlay PFM pada gigi 26 pasca perawatan endodontik. Metode atau tata laksanan kasus terdiri dari penanganan klinik dan laboratorium. Tata laksana laboratorium dilakukan dua tahapan; yakni tahap pembuatan coping metal dan tahap pembentukan lapisan porselen. Coping metal dibuat dengan teknik waxing lapis demi lapis dengan membentuk full metal. Setelah coping terbentuk, pengurangan metal pada bagian bucal, mesio bukal cusp dan distobukal cusp dilakukan hingga mencapai ketebalan $3 \mathrm{~mm}$. Kemudian, bagian tersebut dilapisi dengan bahan porselen. Tahap pelapisan porselen dimulai dari pengulasan opaque, dentin, enamel, dan glazing dengan warna yang sesuai. Hasil dari pembuatan onlay ini; fitting margin cukup baik, warna sesuai dengan yang diintruksikan dokter, perlu dilakukan penyesuaian oklusi karena terdapat prematur kontak dibagian mesio dan disto bukal cusp.
\end{abstract}

Kata Kunci : onlay PFM, perawatan endodontik

\section{Laboratory Case Report Restoration Using Onlay Porcelain Fused To Metal On Post Endodontic Treatment Teeth 26}

\begin{abstract}
Endodontic treatment may result in a reduced tooth hardness of 5\% and a $60 \%$ flexibility. We can solve the problems by doing crown or onlay restoration. Onlay Porcelain Fused To Metal (PFM) can retain most of the gingival-related tissue and this is a very helpful periodontal consideration. The aim of this case report is to describe the success of the making of PFM onlays on post endodontic treatment of the 26 teeth. The method or case layout consisted of clinical and laboratory handling. Laboratory management was carried out in two stages; namely the stage of metal coping and stage formation of porcelain coating (built up). Coping metal was made using waxing technique layer by layer by forming full metal. After coping was formed a new metal reduction on the bucal surface, mesio buccal and distobucal cusps. was done to achieve a thickness of $3 \mathrm{~mm}$ Then, the section was coated with porcelain material. Stage of porcelain coating started from opaque, dentin, enamel, and glazing with appropriate color matching. The result of this onlay making: fitting margin was good enough, the color was according to what the doctor had instructed, but it was necessary to adjust the occlusion because there was premature contact mesio and disto bucal cusps.
\end{abstract}

Keywords: onlay PFM, endodontic treatment

Korespondensi : Suryani Catur S, Jurusan Teknik Gigi Politeknik Kesehatan Tanjungkarang, Jl. SoekarnoHatta No. 1 Bandar Lampung, mobile: 081394322013,e-mail: 6atikko6@gmail.com 


\section{Pendahuluan}

Pada umumnya gigi yang memerlukan perawatan saluran akar adalah gigi yang memiliki restorasi yang besar, karies luas, email yang tidak didukung dentin dan sudah mengenai ruang pulpa. Tindakan preparasi kavitas, pengangkatan jaringan karies, dan juga perawatan saluran akar merupakan tindakan pengambilan dentin yang dapat melemahkan sisa jaringan gigi. Para peneliti menemukan bahwa restorasi untuk gigi yang sudah dirawat endodontic harus dapat meningkatkan fungsi gigi dalam jangka waktu yang lama, untuk itu perencanaan restorasi harus dilakukan dengan teliti dan benar (Haslinda, 2014:12).

Gigi pasca perawatan saluran akar akan menjadi lemah karena adanya pembuangan jaringan dentin pada bagian mahkota dan saluran akar, yang menyebabkan perubahan komposisi struktur gigi. Hilangnya struktur gigi akibat prosedur perawatan saluran akar akan mengurangi kekerasan gigi sebanyak 5\%, sementara hilangnya jaringan mahkota menyebabkan kelenturan berkurang sampai dengan $60 \%$. Kekuatan pada gigi pasca perawatan endodontic, tidak dipengaruhi pada prosedur perawatan saluran akar, akan tetapi preparasi yang luas dapat menyebabkan berkurangnya kekuatan gigi (Fatmawati, 2015:1).

Restorasi onlay dibutuhkan sebagai penghubung bukal dan lingual, karies interproksimal gigi posterior, dan gigi posterior yang menerima tekanan oklusal yang kuat karena tekan kunyah pada onlay diteruskan rata ke jaringan gigi (Baum, Lloyd dkk. 1997 : 403).

Diperoleh kasus cetakan setengah rahang dengan kondisi gigi molar satu kiri rahang atas pasca perawatan endodontik yang telah dipreparasi dengan keterangan permintaan dibuatkan onlay porselen fused to metal.

\section{Metode}

Kasus diperoleh dari model setengah rahang atas, di Laboratorium Teknik Gigi Rumah Sakit Gigi dan Mulut Ladokgi TNI AL RE. Martadinata, Jakarta Pusat pada tanggal 30 Januari - 24 Februari 2017. Kondisi cetakan dengan gigi 26 telah dipreparasi pasca perawatan endodontik. Dokter yang merawat mengintruksikan untuk dibuatkan restorasi onlay porselen fusi metal (PFM).

Penatalaksanaan kasus dilakukan dengan dua tahap, yaitu: tahap pertama pembuatan coping metal, dan tahap kedua pembentukan lapisan porselen.

Skema penatalaksanaan kasus;

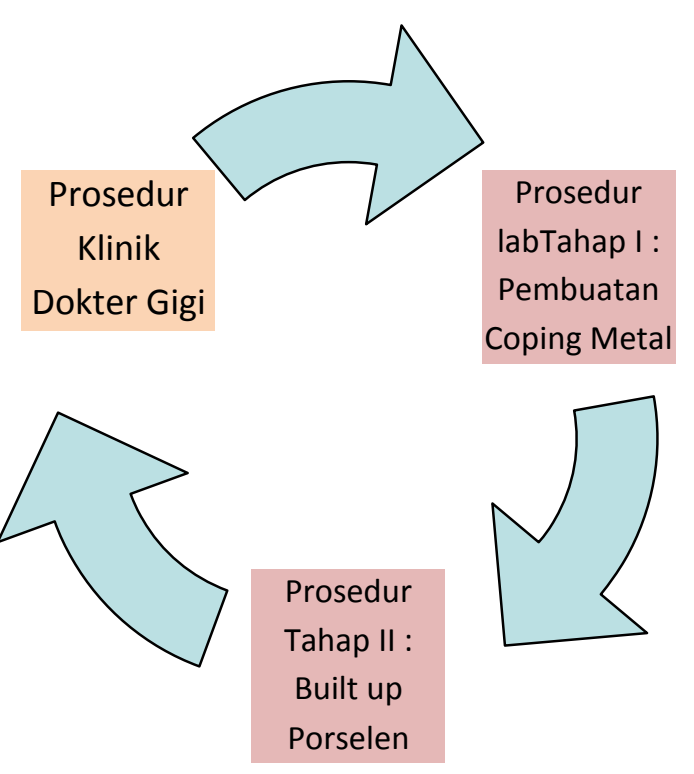

Pada prosedur ini diperlukan alat dan bahan seperti terlihat pada Tabel I.

Tabel 1. Alat dan Bahan

\begin{tabular}{|l|l|}
\hline \multicolumn{1}{|c|}{ Alat } & \multicolumn{1}{|c|}{ Bahan } \\
\hline 1. Mesin Trimmer & 1. Hardener \\
3. Lecron & 2. Die spacer \\
4. Pisau malam & 3. Sparating \\
5. Scapel & 4. Spirtus \\
6. Caliver wax & 5. Macam-macam \\
1. Crucible former & wax (base plate \\
2. Casting ring & wax, wax sprue) \\
3. Vacum machine & 6.Phospat bonded \\
4. Vibrator & invesment \\
5. Burnout Furnice & 7.Cobalt cromium \\
6. Induction casting & 8. Air \\
machine & 9. Liquid opaque, \\
7. Palu & dentin, enamel \\
8. Tang gips & dan transparant \\
9. Mesin sanblaster & 10.Powder \\
10. Micromotor & Opaque, Dentin, \\
11. Caliver metal & Powder, \\
12. Arteri Clamp & transparant, Stain \\
13. Mesin penblaster & dan Glaze \\
14. Kaca & \\
glassplate atau & \\
15. Macam-macam & \\
16. Macam-macam & \\
17. Pisau ukir & \\
18. Tisu kering & \\
19. Porcelain Furnice & \\
20. Shade Guide & \\
21. Spatulaporcelain & \\
& \\
\hline
\end{tabular}


I. Tahap pertama: pembuatan coping metal

Model yang diterima dibersihkan dari nodul dan dirapikan dengan menggunakan mesin trimmer. Untuk mendapatkan model yang kuat dan tidak rapuh, model diulas dengan cairan hardener (gambar 1a). Selanjutnya bagian gigi yang dipreparasi diulas dengan die spacer (gambar 1b).
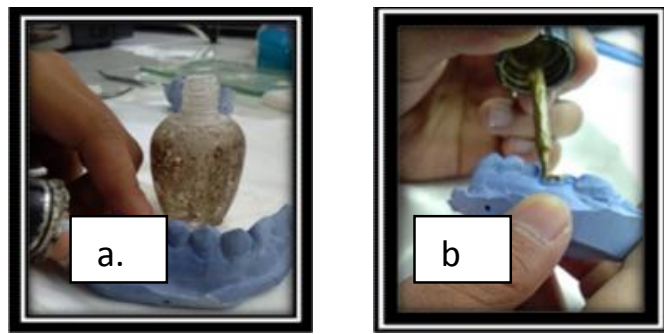

Gambar 1a Pengulasan hardener

1b. Pengulasan die spacer

Pengulasan ini bertujuan untuk memberikan ruang yang cukup bagi bahan penyemenan pada saat restorasi disemenkan pada gigi yang telah dipreparasi. Pengulasan die spacer ini tipis saja untuk menjamin adapatsi yang baik terhadap cavitas setelah restorasi selesai.

Prosedur selanjutnya pengulasan sparating medium pada model gigi yang dipreparasi, yang bertujuan untuk memudahkan pelepasan pola malam dari model kerja. Dilanjutkan dengan pembentukan pola malam dengan teknik lapis demi lapis, sampai bentuk anatomi yang sempurna. Inlay yang digunakan blue inlay wax (gambar 2a). Setelah pola malam selesai, dilanjutkan dengan pemasangan sprue. Tipe sprue tunggal dengan reservoir berbentuk bola dan dipasang membentuk sudut $45^{\circ}$ pada daerah tertebal dari pola malam, memungkinkan logam mengalir dengan sempurna mengisi seluruh mold space (gambar 2b). Pola malam yang sudah terpasang sprue ditanam dalam casting ring dengan bahan tanam tipe higth term phospat bonded. Bahan tanam ini sesuai dengan tipe logam yang dipakai yakni $\mathrm{CoCr}$ yang memiliki titik lebur tinggi (Annusavice, 2004).
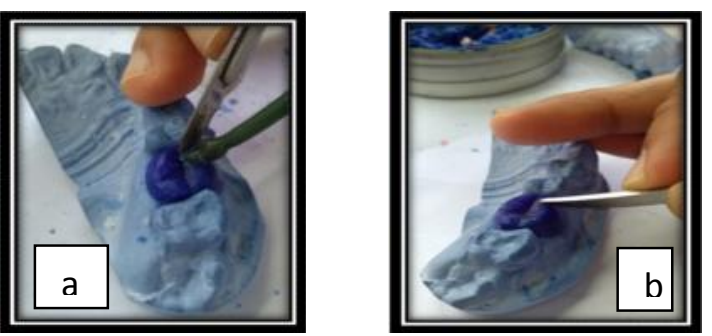

Gambar 2a. Pembentukan pola malam 2b. Pemasangan sprue
II. Tahap kedua : aplikasi porselen

Coping logam yang telah jadi dilakukan pengurangan pada permukaan bukal, mesio bukal cusp dan disto bukal cusp hingga diperoleh ketebalan $0,3 \mathrm{~mm}$ sebagai persiapan aplikasi porselen. Kemudian dilakukan pen balsting pada permukaan bukal, mesio bukal cusp dan disto bukal cusp untuk mendapatkan porositas mikro sebagai sarana retensi antar bahan porselen dan coping. Selajutnya coping dibersihkan dengan air mengalir dan dikeringkan.

Prosedur aplikasi diawali dengan aplikasi lapisan opaque sebanyak dua lapis kemudian dibakar dalan porcelain furnace. Di atas lapisan opaque dilakukan pelapisan dentin, enamel dan transparant dalam satu step sampai diperoleh bentuk anatomi yang sempurna, dengan ukuran yang lebih besar dari ukuran ynag diharapkan. Tahap selanjutnya restorasi dibakar kembali dalam porcelain furnace pada.

Setelah proses pembakaran lapisan enamel dan dentin selesai, dilanjutkan dengan tahap carving menggunakan micromotor dan mata bur green stone. Proses ini dilakukan untuk menyem- purnakan bentuk anatomi gigi sesuai dengan gigi molar satu kiri rahang atas dan untuk mendapatkan oklusi yang baik.

Setelah carving selesai dilanjutkan dengan pengulasan staining dan glazing. Tahap ini bertujuan untuk memberikan corak yang lebih alami dan gigi akan nampak asli. Untuk mendapatkan hasil yang lebih maksimal dilakukan pemolesan pada bagian metal (permukaan palatal) sampai mengkilap.

Hasil akhir restorasi dapat dilihat pada gambar dibawah ini (gambar 3a dan 3b).
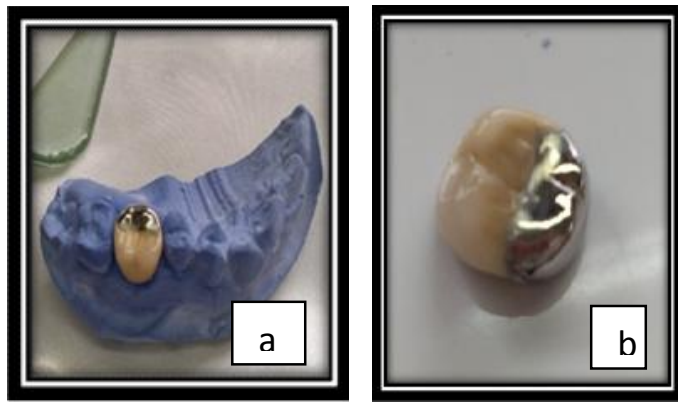

Gambar 3a, 3b . Hasil Akhir restorasi

Hasil akhir restorasi onlay porcelain fus 1 metal diinsersikan pada model dan hasilnya sebagai berikut: fitting pada model baik (cekat), warna sesuai dengan surat perintah kerja, oklusi baik, kontak proksimal tepat, kontur bukal lebih cembung dari gigi tetangganya (gambar $3 a$ dan $3 b)$. 


\section{Pembahasan}

Perawatan endodonik bertujuan mempertahankan jaringan gigi semaksimal mungkin. Perawatan ini mengakibatkan hilangnya kontinuitas jaringan gigi sehingga sebagian struktur gigi mudah mengalami kerusakan. Untuk mempertahankan sebagian srtuktur gigi perlu dilakukan restorasi.

Restorasi akhir gigi pasca perawatan endodontic merupakan bagian integral kunci keberhasilan. Restorasi yang ideal harus dapat melindungi permukaan oklusal dan menggantikan tonjol - tonjol yang hilang agar dapat secara optimal melindungi struktur mahkota gigi dan menambah ketahanan. Restorasi onlay porselen fused to metal (PFM) merupakan salah satu pilihan yang menguntungkan. Karena restorasi ini dapat mempertahankan sebagian besar jaringan gigi yang berhubungan dengan gingival dan hal ini merupakan suatu pertimbangan periodontal yang sangat membantu. Restorasi onlay dapat menghubungkan kontinuinitas jaringan mahkota gigi pada permukaan bukal, lingual, oklusal dan interproksimal untuk meneruskan tekanan kunyah ke jaringan periodontal (Baum, Lloyd dkk. 1997 : 544).

Restorasi onlay porcelain fused to metal (PFM) memberikan keuntungan: estetik bagus dan kuat di semua tempat dari lengkung gigi, ketidaksempurnaan dalam preparasi dapat dikompensasi oleh struktur dasar logam (coping), dan kerapatan pada bagian servical lebih baik dibanding dengan mahkota jaket (Kayser, 1984: 202).

Pada tahap pembuatan coping metal; model kerja dilapisi cairan hardener sebagai penguat model agar tidak mudah patah/ model menjadi lebih keras, sehingga diperoleh adaptasi yang baik pada bagian cervikal. Disamping itu penggunaan die spacer dan secara hati-hati akan memberikan hasil waxing coping metal yang baik, sehingga fitting coping metal lebih optimal.

Pembentukan lapisan porselen dilakukan secara bertahap lapis demi lapis. Lapisan dasar: opaque dimaksudkan untuk menyamarkan warna logam, karena lapisan porselen memiliki sifat tarnslusen. Sehingga apabila tidak diberi lapisan opaque maka warna logam akan terpancar ke luar dan ini tidak menguntungkan secara estetik. Pada kasus ini dilakukan pelapisan sebanyak dua kali untuk menghasilkan warna yang lebih baik.

Untuk menghasilkan bentuk anatomis dan warna yang diinginkan dilakukan pelapisan dentin dan enamel. Pembentukan (built up) lapisan ini diperbesar sedikit dari ukuran anatomis gigi asli. Teknik ini bertujuan untuk menyediakan kompensasi pengerutan setelah pembakaran sehingga akan diperoleh ukuran anatomis sesuai gigi aslinya. Tahap berikutnya yang tak kalah penting adalah merapikan konstruksi porselen serta membuat pit dan fisure layaknya gigi asli dengan menggunakan diamond boor.

Tahap selanjutnya adalah membersihkan restorasi dengan ultrasonic cleaner, kemudian pemolesan dengan silicon rubber. Tahapan ini juga penting untuk mendapatkan permukaan porselen yang bersih sehingga adaptasi lapisan staning dan glaszing sempurna.

Restorasi akhir yang dihasilkan terlihat: fiting margin baik, warna sesuai, oklusi baik. Namun pada saat restorasi diinsersikan pada cavitas terjadi peninggian gigitan sehingga menyebabkan oklusi traumatik. Oleh karena itu dokter yang merawat melakukan pengurangan pada permukaan mesio dan disto bukal cusp sehingga sebagian lapisan porselen terpaksa harus digrinding.

Peninggian gigitan ini tentu saja sangat merugikan. Hal ini disebabkan jeda waktu antara pencetakan model dan pembuatan onlay sampai dengan proses insersi cukup lama, sehingga terjadi perubahan oklusi gigi, sehingga jarak interoklusal berkurang atau memendek.

\section{Kesimpulan}

Restorasi onlay porselen fusi metal merupakan salah satu pilihan dalam membantu keberhasilan perawatan endodontik. Porselen fusi metal memberikan keuntungan dari segi kekuatan dan estetika.

Hasil akhir kasus pembuatan restorasi onlay porselen memberikan hasil yang baik karena dari segi warna sesuai dengan yang diharapkan, fiting margin baik, namun mengalami sedikit kendala dalam penyesuaian oklusi. Oleh karena itu untuk menghasilkan suatu restorasi yang baik dan dapat diterima oleh dokter gigi serta pasien diperlukan cetakan yang akurat dan cetakan terbaru.

\section{Ucapan Terima Kasih}

Ucapan terimakasih disampaikan kepada ; drg. Dwina Ariadno, Sp.Pros, drg. Dewi 
Pandanarum, Sp. KG, yang telah mengijinkan kasus ini diangkat sebagai karya ilmiah.

\section{DAFTAR PUSTAKA}

1. Annusavice, Kenneth. J. 2004. Philip's Science of Dental Material Edisi 10. Diterjemahkan oleh Johan Arief Budiman dan Susi Purwoko. Jakarta: EGC. 356 halaman.

2. Baum, Lloyd. 1997. Text Book of Operative Dentistry. Saunders Company: United States of Amerika

3. Fatmawati, Dwi W.A, 2015. "Macam Macam Restorasi Rigid Pasca Perawatan Endodontia”, Jember, Universitas Jember .

4. Fujimoto,dkk.2001.Contemporary Fixed Prosthodontics.Louis.Westline Industrial.

5. Haslinda, Nugroho Juni Jekti, 2014. "Restorasi Onlay pada Gigi Molar Pertama Rahang Atas Pasca Perawatan Endodontik”, Makassar, Universitas Hasanuddin .

6. Kayser, at all. 1984. Gigi yang Rusak dan Perawatannya dengan Mahkota dan Jembatan. Hak Penerbit Edisi Indonesia pada Binacipta. 288 halaman.

7. Kidd, E.A.M; B.G.N. Smith; H.M. Pickard. 1993. Manual Konservasi Restoratif menurut Pickard (Pickard's Manual of Operative Dentistry ). Edisi ke6 diterjemahkan oleh Ahli Bahasa Narlan Sumawinata. Jakarta: Penerbit Widya Medika. 206 halaman.

8. Martanto, P. 1982. Teori dan Praktek Ilmu Mahkota dan Jembatan. Jilid 2. Bandung: Alumni. 298 halaman

9. Richard,Bence. 1990. Buku Pedoman Endodontik Klinik. Jakarata. 